\title{
Factors Affecting the Incomes of Peasant Households Affected by Climate Change in Tra Vinh Province, Viet Nam
}

\author{
Ha Hong Nguyen ${ }^{1} \&$ Trung Thanh Nguyen ${ }^{2}$ \\ ${ }^{1}$ Department of Finance and Banking, Tra Vinh University, Viet Nam \\ 2 Tra Vinh University, Viet Nam \\ Correspondence: Ha Hong Nguyen, Associate Professor, Ph.D. Lecturer, Head of Department of Finance and \\ Banking, Tra Vinh University, Viet Nam. Tel: 84-2943-855-246.
}

Received: January 21, 2020

Accepted: February 24, 2020

Online Published: March 6, 2020

doi:10.5430/rwe.v11n1p130

URL: https://doi.org/10.5430/rwe.v11n1p130

\begin{abstract}
The results of this study aim to propose implicational policies for the People's Committee of Tra Vinh province, Viet Nam; Department of Agriculture and Rural Development of Tra Vinh province and related departments in Tra Vinh province. Thanks to these results, they may have effective solutions to support peasants who can have new circumstances in the areas of climate change due to adaptive salinization. It can also be stated that it is very necessary to find solutions to raise their incomes, improve better lives in the future. Studying factors on incomes of peasants' households affected by climate change by direct interview method of 280 households, in 07 districts including: Tra Cu, Cau Ngang, Chau Thanh, Duyen Hai, Tieu Can, Cau Ke and Tra Vinh city in the regions affected by climate change in Tra Vinh province. By using multivariate regression method, the authors have found out the factors affecting peasants' income in these regions: Diversifying income generation activities, demanding for bank loans, education, work experience and land areas of households. From the research results, it can be proposed the solutions to increase peasants' income to adapt to climate change in these areas in the future.
\end{abstract}

Keywords: climate change, salinization, income, diversification, peasants

JEL Classification code: Q54, J30, J43, O18, Q13

\section{Introduction}

It cannot be denied that Vietnam is one of the most vulnerable countries to natural disasters in the world. Natural disasters in Vietnam consist of typhoons, high tides, floods in rivers and streams, landslides due to heavy rains and drought, salinity and so on. On average, about one million people in Vietnam have been affected by natural disasters including floods in the Mekong Delta. The damage caused by floods has increased in recent decades and this trend can develop more heavily due to typhoons and precipitation and the consequences of climate change (Viner.D and Bouwer, L. 2006). The effects of climate change also mean that gradual changes that increase the dangers of hazards which can greatly affect Vietnam's capacity to achieve millennium goals. These include the possibility of worsening gender inequality, more work burdens for women because they could have fewer assets and resources (Ministry of Natural Resources and the Environment, 2013).

In recent years, Tra Vinh province, a coastal province in Mekong Delta, has been paid special attention by many authorities and local people who have implemented many measures to cope with climate change and salinization and they have partly limited the impact of salinization on production and local people's lives. However, the effectiveness is not high, the consequences of salinization are still at high level directly affecting the lives of people (especially those who live on agricultural areas). Therefore, the research on the impacts of climate change, particularly salinization on the lives and incomes of local households, can consist of urgent issues (Department of Agriculture and Rural Development of Tra Vinh province, 2018).

\section{Literature Review}

Nguyen Tien Dung (2014) conducted a survey of 190 peasants' households in districts of Can Tho city to analyze the impacts on the peasants' incomes. The research methods used in this study are descriptive statistics and multivariate regressions, the study also identified factors such as cultivated areas, production expenditure, rice price, rice yield and gender influence which strongly impact to people's incomes (Nguyen Lan Duyen (2014); Do Huu Nghi (2016) 
who identify the factors affecting the income of households in the affected areas. Multivariate regression was used to test the correlation between the factors which affect households' incomes, and the results of the study shows that there are five factors affecting the incomes of households in the climate change affected areas. The effects such as the number of labor in agriculture, the number of non-agricultural employees, the number of years of project implementation, the items from home to market and the education of the households' heads.

Truong Van Hieu (2016), proposed solutions namely: upgrading and renewing dyke systems and saline gates; dredging irrigation canals of grades 2 and 3; reinforcing the renovation or renewal of freshwater reserve ponds. At the same time, they also combined with the collection, storage, management and rational uses of fresh water to improve water shortages due to salinization in agricultural production. The peasants' incomes can be influenced by many factors including capital, land, education, production experience, number of employees, ability to diversify incomes, and market access opportunities (Abdulai. \& CroleRees, 2001; Demurger et al., 2010; Janvry \& Sadoulet, 2001). It is obvious that capital plays an indispensable role because peasants need capital to buy materials, seeds, machines, hire labor and so on to ensure seasonality and minimize risks, thereby increasing incomes (Klasen et al., 2013; Yang, 2004; Yu \& Zhu, 2013). In addition, capital also helps peasants investing in developing irrigation systems as well as applying new techniques to diversify production types to avoid having to sell produce at low prices (Khan A.R., 1993). In particular, many cash loans made before harvest (at a time when the price of agricultural products are high) must be returned in kind after the harvest (at a time when the price of agricultural products is low), resulting in higher interest rates. High interest rates increase production costs, thereby reduce peasants' incomes (Isis. G \& Stephan. K. (2014).

Due to the characteristics of perishable agricultural products that are difficult to preserve and harvest (seasonally), peasants often sell produce at low prices to traders right after harvest (oversupply). This shows that peasants living near urban areas (towns, towns, cities or cities) will be able to sell produce directly to consumers with higher prices, lower transportation costs and the produce is less damaged so the income is higher (Nguyen Lan Duyen, 2014).

In terms of agriculture, land is the main means of production and difficult to replace. Because most of the households' incomes depend on agricultural production, agricultural production in our country is mainly manual and based on land, so the size of the land will mainly derivates incomes. The lack of or little land of production limits the ability to improve incomes. Because the small area makes it difficult to apply modern farming techniques, the produce is low quality, unequal but the price is high (Manjunatha et al., 2013).

It cannot be denied that labor is also an important input of agricultural production, not only quantity but also quality. In less mechanized production conditions, the number of employees will be a key factor in increasing peasants' incomes (Abdulai \& CroleRees, 2001; Demurger et al, 2010). The number of laborers working in the non-agricultural activities can be limited, making it difficult to engage in non-agricultural activities so rural households may have more labors but not high incomes because some workers do not directly generate incomes.

One more key factor is education which plays a key role for the development of every single individual, every single organization as well as every single nation (Foster \& Rosenzweig, 1996; Pitt \& Sumodiningrat, 1991; Yang, 2004). It can be stated that education determines each person's advantage in generating income because well-educated conditions will be receptive, applying new technologies to production and effectively using other resources. In addition, education also enhances the ability to capture and process market information to create opportunities for participating in non-agricultural activities, thereby increasing income.

Beside education, the time living in the locality also affects the incomes of the peasants. The peasants who live in the locality for a long time are often assisted by relatives and social organizations (in terms of capital and production experience) when necessary thanks to kinship and community relations. In addition, these households also have better living conditions, production and accumulation because in terms of Vietnamese culture "Settling with a house, having a stable life". (Nguyen Thanh Binh, 2012).

In general, the above researches focused on addressing climate change issues and the response of people in a specific area. No studies have been conducted in a province like Tra Vinh, Viet nam, one of the country is most affected by climate change in Southeast Asia. Studies inside and outside Vietnam have suggested that the adaptation of the people is an important condition for improving the life in the current situation and the studies have not solved specific issues for farmers. In order to improve the incomes and economic conditions of farmers in localities in Vietnam in the context of ongoing climate change. 


\section{Research Methodology}

Based on theory and empirical studies, we have the the analytical framework including 10 factors affecting rural households' incomes; The authors developed a model to analyze the factors affecting the incomes of households affected by climate change in the province.

The model of analyzing the factors affecting households' incomes in climate change areas is shown by the following multivariate regression function:

$$
\mathrm{Y}=\beta 0+\beta 1 \mathrm{X} 1+\beta 2 \mathrm{X} 2+\beta \mathrm{n} \mathrm{Xn}+\alpha
$$

In which:

Y: Dependent variable; Xi: Independent variable (i=1-10)

Table 1. A summary of variables in the model

\begin{tabular}{|c|c|c|c|c|}
\hline No. & $\begin{array}{c}\text { Variables } \\
\text { codes }\end{array}$ & Names of Variables & Selecting variable sources & $\begin{array}{l}\text { Expectations of } \\
\text { Variables }\end{array}$ \\
\hline 1 & $\mathrm{Y}$ & $\begin{array}{l}\text { Households' incomes: } \\
\text { The dependent variable of households' incomes } \\
\text { Average households' incomes }\end{array}$ & $\begin{array}{l}\text { Park (1992), Scoones (1998), } \\
\text { Mincer (1974); Nguyen Thanh } \\
\text { Binh (2012) }\end{array}$ & $+/-$ \\
\hline 2 & $\mathrm{X}_{1}$ & $\begin{array}{l}\text { Households' jobs: } \\
\text { The fake variable takes a value of } 1 \text { if the head } \\
\text { of the household is in non-agriculture work, } \\
\text { and a value of } 0 \text { if the head of household is in } \\
\text { agriculture. }\end{array}$ & $\begin{array}{l}\text { Abdulai \& CroleRees, (2001); } \\
\text { Demurger et al (2010); Nguyen } \\
\text { Tien Dung (2014) }\end{array}$ & + \\
\hline 3 & $\mathrm{X}_{2}$ & $\begin{array}{l}\text { Households' experience: } \\
\text { The number of working years of heads of } \\
\text { households (in year) }\end{array}$ & $\begin{array}{l}\text { Mincer (1974); Manjunatha et } \\
\text { al (2013); Abdulai \& } \\
\text { CroleRees, (2001); Demurger } \\
\text { et al, (2010) }\end{array}$ & + \\
\hline 4 & $X_{3}$ & $\begin{array}{l}\text { The households' educational levels: } \\
\text { The number of years of school work (in year) }\end{array}$ & $\begin{array}{l}\text { Do Huu Nghi (2016); Mincen } \\
\text { (2009); Truong Van Hieu } \\
\text { (2016); }\end{array}$ & + \\
\hline 5 & $\mathrm{X}_{4}$ & $\begin{array}{l}\text { Household heads' gender: } \\
\text { The fake variable receives a value of } 1 \text { if the } \\
\text { head of household is male, and a value of } 0 \text { if } \\
\text { the head of household is female. }\end{array}$ & $\begin{array}{l}\text { Truong Van Hieu (2016); Pitt } \\
\text { \& Sumodiningrat, (1991); Yang } \\
\text { (2004); }\end{array}$ & + \\
\hline 6 & $\mathrm{X}_{5}$ & $\begin{array}{l}\text { Household heads' ethnic: } \\
\text { The fake variable receives a value of } 1 \text { if the } \\
\text { head of household is Kinh, and a value of } 0 \text { if } \\
\text { the head of household is ethnic minority. }\end{array}$ & $\begin{array}{l}\text { Nguyen Lan Duyen (2014); Pitt } \\
\text { \& Sumodiningrat (1991); Yang } \\
\text { (2004); }\end{array}$ & + \\
\hline 7 & $\mathrm{X}_{6}$ & $\begin{array}{l}\text { Households' size: } \\
\text { The number of people living in the households, } \\
\text { excluding employees, dependent people } \\
\text { (people) }\end{array}$ & $\begin{array}{l}\text { Truong Van Hieu (2016); } \\
\text { Mincer (1974); Manjunatha et } \\
\text { al (2013); Abdulai \& CroleRees } \\
\text { (2001); Demurger et al (2010) }\end{array}$ & + \\
\hline 8 & $\mathrm{X}_{7}$ & $\begin{array}{l}\text { Dependency ratio: } \\
\text { Measuring the percentage }(\%) \text { of total } \\
\text { non-working-age people in the total working-age } \\
\text { population }(\%)\end{array}$ & $\begin{array}{l}\text { Nguyen Lan Duyen (2014); } \\
\text { Karttunen (2009); Demurger et } \\
\text { al (2010); Janvry \& Sadoulet } \\
\text { (2001) }\end{array}$ & + \\
\hline
\end{tabular}




\begin{tabular}{|c|c|c|c|c|}
\hline 9 & $X_{8}$ & $\begin{array}{l}\text { Scale of land area: } \\
\text { Production land area of the households }\left(\mathrm{m}^{2}\right)\end{array}$ & $\begin{array}{l}\text { Truong Van Hieu (2014); } \\
\text { (Klasen et al (2013); Yang } \\
\text { (2004); Yu \& Zhu (2013) }\end{array}$ & + \\
\hline 10 & $\mathrm{X}_{9}$ & $\begin{array}{l}\text { The number of income generating activities: } \\
\text { Households' The number of income generating } \\
\text { activities. }\end{array}$ & Experts' survey (2017) & + \\
\hline 11 & $\mathrm{X}_{10}$ & $\begin{array}{l}\text { Loan: } \\
\text { The fake variable receives value } 1 \text { if the } \\
\text { households have a loan, receives a value of } 0 \text { if } \\
\text { not having a loan. }\end{array}$ & $\begin{array}{l}\text { Scoones (1998) and experts' } \\
\text { survey (2019); Isis. G \& } \\
\text { Stephan. K (2014). }\end{array}$ & + \\
\hline
\end{tabular}

Sources: A summary of the authors' model research

After identifying the research areas, we then conducted the household interviews by using a prepared survey questionnaire which was used to collect fundamental household information. After interviewing 280 households, we continued to conduct an in-depth interview to gain a better understanding of the local income generating activities, experiences and perceptions of responding to the impacts of climate change. The requirements of a questionnaire are both generalization (representative for the research areas) and specific aspects (differences in living standards, geographical location and so on) and meet the purpose of the test, check the logic of the question system (ie exclusion, coherence and so on to cross-check, detect errors, evaluate reliability and so on).

\section{Research Results}

The authors conducted regression analysis on the independent variables: Head of households' occupation, household heads' work experience, household heads' educational level, gender of head of households, household heads' ethnicity, households' sizes, dependency ratios, the sizes of land area, diversification of income-generating activities, borrowing to determine the degree of influence and impact of these variables on the income of peasants' households. After using SPSS software for analysis, the following results were obtained:

Table 2. Regression results

\begin{tabular}{|c|c|c|c|c|c|c|c|c|}
\hline & \multirow[t]{2}{*}{ Model } & \multicolumn{2}{|c|}{$\begin{array}{l}\text { Unstandardized } \\
\text { Coefficients }\end{array}$} & \multirow{2}{*}{$\begin{array}{c}\text { Standardized } \\
\text { Coefficients } \\
\text { Beta }\end{array}$} & \multirow[t]{2}{*}{$\mathbf{T}$} & \multirow[t]{2}{*}{ Sig. } & \multicolumn{2}{|c|}{ Collinearity Statistics } \\
\hline & & B & Std. Error & & & & Tolerance & VIF \\
\hline \multirow{11}{*}{1} & (Constant) & 45.213 & 13.327 & & 3.393 & .000 & & \\
\hline & Occupation & 4.580 & 5.466 & .032 & 2.838 & $.042 * *$ & .933 & 1.072 \\
\hline & Experience & 1.920 & .352 & .449 & 5.449 & $.019 * *$ & .756 & 1.324 \\
\hline & Educational level & 2.917 & 2.085 & .065 & 6.846 & $.007 * * *$ & .874 & 1.144 \\
\hline & Gender & 26.506 & 6.627 & .338 & 4.001 & $.029 * *$ & .716 & 1.396 \\
\hline & Ethicity & -3.352 & 5.787 & -.046 & -.579 & $.458^{\mathrm{ns}}$ & .824 & 1.213 \\
\hline & Households' size & -1.033 & 1.207 & -.066 & -.855 & $.794^{\mathrm{ns}}$ & .866 & 1.155 \\
\hline & Dependency size & -.032 & .038 & -.062 & -.835 & $.397^{\mathrm{ns}}$ & .944 & 1.059 \\
\hline & Acreage & .154 & 1.037 & .012 & .149 & $.034 * *$ & .831 & 1.204 \\
\hline & Diversification & 10.883 & 4.396 & .214 & 2.476 & $.000 * * *$ & .685 & 1.459 \\
\hline & Loan & 15.940 & 5.642 & .214 & 2.825 & $.000 * * *$ & .895 & 1.118 \\
\hline
\end{tabular}

Dependent variables: Incomes; $* * *, * *$ The significant meanings: $99 \%, 95 \%$

Source: The results of multivariate regression analysis

In the Table 2, it can be easily observed that the test the collinearity phenomenon of the independent variables, variance (VIF) is less than 10 . Therefore, the independent variables are not mutually correlated. The estimated results 
of the model show that out of 10 independent variables included in the research model, 6 variables have statistically significant impacts on households' incomes: Occupation; Experience; Education; Sex; Acreage; Diversification; Loans are statistically significant. These variables have statistical significance at $5 \%$ and $1 \%$. Specifically, the variables Education level; income diversification and loan have a statistically significant impact of $1 \%$ on peasants' incomes. The Occupational; experience; gender, the land area variables are 5\% significant.

The remaining variables such as Ethnicity; Household size and dependency ratios which are not statistically significant and do not affect households' incomes in the climate change areas.

It could be specifically stated that Occupational variables have the same direction of incomes. With the assumption of other factors being constant, when a peasant works in the non-agricultural sector, the income of that one will be higher than that of the one working in the agricultural sector 4,580 million VND/year, with a 95\% significance level. Experience variables have a positive effect on Income. When the head of the household has one more year of experience, their income will increase by VND 1,329 million/year, with a 95\% significance level.

The variations in Educational level of the household heads are positively affected in the same direction as the income variable when the educational level assumes that other factors remain constant, the household heads' education increases by 1 class, the households' income will increase by VND 2,101 million.

In terms of Gender, it has a positive impact in the same direction with the assumption that other factors remain the same. When the gender of a household head is male, that household's income will be higher than VND 26,506 million compared to female headed households.

In terms of Acreage variable, it has a positive acting in the same direction as the Income variable, assuming that other factors remain unchanged, when the land area of the household heads increases by 1 unit, the households' income will increase by VND 0.963 million.

In terms of Diversification variable, the income impacts in the same direction with the assumption that other factors remain unchanged; When the income increases by another business activity, the household's income will increase by VND 14,799 million.

In terms of Loan variable, it impacts in the same direction with the assumption that other factors remain unchanged; The household's income increased by 11,397 million VND compared to non-loaning households.

\section{Suggested Climate Change Adaptation Solutions in Tra Vinh Province, Viet Nam}

\subsection{A solution on Plants and Aquatic Varieties}

Seed selection cou be recognized as the first adaptation to ensure continuous production (Smit \& Skinner, 2002). According to the World Food Organization FAO (2007), it is very necessary to select seeds that are able to tolerate high temperatures, droughts, floods, salinity and disease resistance to adapt to climate change and salinity at present. According to the 2016 recommendations of the Department of Agriculture and Rural Development, drought-resistant, saline and alum-tolerant rice seeds to be adapted in Tra Vinh province.

\subsection{Paying Attention to the Seasonal Calendar}

It could be claimed that the seasonality of agricultural and fishery production depends on many factors including climate and salinity. In the scope of AMD project, Tra Vinh has invested in salinity measuring and forecasting system to support agricultural and fishery production. The annual crop calendar is adjusted to suit the weather forecast and salinity in the province. Specifically speaking, in 2018, the Department of Agriculture and Rural Development of Tra Vinh adjusted the seasonal calendar for rice seeding later than one month compared to the 2017 seasonal calendar.

\subsection{Focusing on Improving Farming Techniques}

In Tra Vinh, some vegetable production areas apply water-saving cultivation techniques such as using mulch, drip irrigation, and rain spraying. The productivity can be improved in terms of saving water and care time. However, this technique has not yet been widely applied because most of poor people are not economically capable to invest this technique in production. Therefore, the State should have financial policies to prioritize investment in agricultural and fishery production to help them adapt to climate change.

\subsection{Solutions on Income Diversification}

The activities on diversifying income would contribute to increase households' incomes. When the factor of labor from the main source of production labor is limited, increasing other sources of income can be an indispensable solution to bring more incomes to the households. Again, the activities on diversifying income will increase 
households' incomes. Therefore, to increase income, it could be vital for peasants to diversify income-generating activities, low-income households should actively participate in vocational training to participate in creating more income-generating activities, especially non-agricultural activities to promote the available resources of households. It could also be necessary for local authorities to promote more vocational training classes for peasants, at the same time there should be policies to support production facilities, cooperative economic organizations, businesses, farm owners.

\subsection{Supplying More Credit Packages to Support Households}

It could be clearly stated that capital for production is an important factor determining the production scale of the households, the household economic model borrows capital for production development of the banks, the preferential credit interest rate model for the poor, and credit through Women's Unions and so on have been formed and widely developed but not everyone can borrow money because the government has strict regulations, especially for the poor because they are not qualified in many aspects so many households have to borrow money from outside organizations which have very high interest rates, which strongly affects production capacity. Therefore, it can be strongly suggested that the borrowers of the bank must be the real households' heads who really need capital for production and business, using in the right purposes, not for consumption. In short, more preferential measures should be offered to the poor.

\subsection{Improving Education Level to Response Climate Change Challenges}

The research results clearly show that educational level directly affects households' incomes. Besides, in order to achieve higher incomes, the peasants must participate in the professions that require high qualifications. Therefore, it is essential for them to improve the educational level, especially in the current conditions in which the application of scientific and technological advances in the field of agriculture-industry and services is increasing. The peasants must have sufficient knowledge to meet the standards and market requirements in order to raise the incomes of peasants who must invest in school work.

\section{Conclusion}

This study addresses farmers' incomes improvement issues in the conditions of climate change in Tra Vinh Province and Viet Nam. The contributions of the study recommend the Government of Viet Nam and Tra Vinh province need to quickly applying modern technology in agriculture, improve the quality of plant varieties, train farmers on farming techniques and crops; attaching importance to the seasonal calendar, as well as the credit policy for agriculture and rural areas in the context of annual climate change.

\section{Acknowledgements}

The authors sincerely thank the support and assistance of the survey team of Faculty of Economics, Tra Vinh University; Department of Agriculture and Rural Development of Tra Vinh province and 280 households living in 07 districts including: Tra Cu, Cau Ngang, Chau Thanh, Duyen Hai, Tieu Can, Cau Ke and Tra Vinh city. The authors sincerely thank the enthusiastic support of these research groups.

\section{References}

Abdulai, A., \& CroleRees, A. (2001). Determinants of Income Diversification amongst Rural Households in Southern Mali. Food Policy, 26, 437-452. https://doi.org/10.1016/S0306-9192(01)00013-6

Demurger, S., Fournier, M., \& Yang, W. (2010), Rural Households' Decisions towards Income Diversification: Evidence from a Township in Northern China. China Economic Review, 457, 1-13.

Démurger, Sylvie and Fournier, Martin, Poverty and Firewood Consumption. (2010). A Case Study of Rural Households in Northern China. GATE Working Paper No. 1020. https://doi.org/10.2139/ssrn.1687527

Department of Natural Resources and Environment of Tra Vinh Province. (2016). Tra Vinh climate change scenario, 3-5.

Do, H. N. (2016). Factors affecting household income in the project's affected area in Binh Thuy district of Can Tho city. Scientific Journal of an Giang University, 104-111

F.A.O. (2007). State of the World's Forests 2007; Food and Agriculture Organization of the United Nations. Electronic Publishing Policy and Support Branch Communication Division, 13-19.

Foster, A. D., \& Rosenzweig, M. R. (1996, September). Technical Change and Human-Capital Returns and Investments: Evidence from the Green Revolution. American Economic Review, 86(4), 931-953. 
Ian, S. (1998). Sustainable rural liverlihoods: A Framework for Analysis. Institute of Development Studies, 72.

Isis, G., \& Stephan, K. (2014, July). Economic development, structural change, and women's labor force participation: A reexamination of the feminization U hypothesis. Journal of Population Economics, 27(3), 639-681. Retrieved from https://www.jstor.org/stable/44289679

Jacob, M. (1974). Family Investment in Human Capital: Earnings of Women. Journal of Political Economy, 82(2), S76-S108.

Janvry, A. de, \& Sadoulet, E. (2001). Income Strategies Among Rural Households in Mexico: The Role of Off-farm Activities. World Development, 29(3), 467-480.

Khan, A. R. (1993). The determinants of household income in rural China. In K. Griffin, \& R. Zhao (Eds.), The distribution of Income in China (pp. 95-115). St. Martin's Press. New York.

Klasen, S., Priebe, J., \& Rudolf, R. (2013). Cash Crop Choice and Income Dynamics in Rural Areas: Evidence for Post-crisis Indonesia. Agricultural Economics, 44, 349-364.

Manjunatha, S. S., \& Raju, P. S. (2013). Modelling the Rheological behaviour of tender coconut (Cocos nucifera L) water and its concentrates. International Food Research Journal, 20(2), 731-743.

Ministry of Natural Resources and the Environment. (2013). Viet nam Environment climate change. Retrieved from https://www.adb.org/sites/default/files/institutional-document/33916/files/viet-nam-environment-climate-chang e.pdf

Nguyen Thanh Binh. (2012). Participatory vulnerability assessment: the case of saline intrusion in the Mekong Delta, Vietnam. Science Magazine of Can Tho University, 229-239.

Nguyen, L. D. (2014). Factors affecting to household incomes in An Giang. Journal of Science An Giang University, $3(2), 63-69$.

Nguyen, T. D. (2014). Factors affecting the income of rice farmers in Can Tho. Scientific Journal of Can Tho University, 117-123.

Pitt, M. M., \& Sumodiningrat, G. (1991, May). Risk, Schooling and the Choice of Seed Technology in Developing Countries: A Meta-Profit Function Approach. International Economic Review, 32(2), 457-473.

Smit and Skinner. (2002). Adaptation options in agriculture to climate change: A topology. Mitigation and Adaptation Strategies for Global, 7(1), 85-114. https://doi.org/10.1023/A:1015862228270

Truong Van Hieu. (2016). Impacts of climate change: saline intrusion on agricultural production in Tra Vinh. Climate Change Office of Tra Vinh Province, 03-05.

Viner, D., \& Bouwer, L. (2006). Linking Climate Change Adaptation and Disaster Risk Management for Sustainable Poverty Reduction- Viet nam country study. European Commission, Vulnerability and adaptation resource group. Retrieved from http://gcca.eu/usr/documents/EC-VARG-vietnamstudy_2010107165747.pdf

Yang, D. (2004). Education and Allocative Efficiency: Household Income Growth during Rural Reforms in China. Journal of Development Economics, 74, 137-162.

Yu, J., \& Zhu, G. (2013). How Uncertain Is Household Income in China. Economics Letters, 120, 74-78. 